\title{
PESANTREN MANHAJ SALAFI: PENDIDIKAN ISLAM MODEL BARU DI INDONESIA
}

\author{
Irham \\ UIN Syarif Hidayatullah Jakarta \\ Email: irham.muu@gmail.com
}

\begin{abstract}
This article explains the devolopment of Islamic education in Indonesia, especially in pesantren (Islamic Boarding School) which is salafi manhaj. It aims at finding islamic education model developed at salafi manhaj pesantren. It uses library research. This article concludes that salafi manhaj pesantren currently becomes new model of Islamic education in Indonesia. This model differs from those applied in most pesantrens in Indonesia. The factor triggering its development is the effect of the transnational of Islam. This factor can further complete the theory of Islamic education change in Indonesia proposed by Karel Steenbrink.

Artikel ini menjelaskan tentang perkembangan pendidikan Islam di Indonesia. Fokus pembahasannya adalah pesantren yang bermanhaj salafi. Artikel ini bertujuan untuk menemukan bentuk pendidikan Islam yang berkembang pada pesantren yang berideologi salafi (manhaj salafi). Kajian ini menggunakan metode kepustakaan. Artikel ini menyimpulkan bahwasanya pesantren bermanhaj salafi merupakan bentuk pendidikan Islam model baru di Indonesia saat ini. Model pesantren ini berbeda dengan pesantren pada umumnya yang sudah lama berkembang di Indonesia. Faktor pemicu perkembangannya adalah pengaruh dari Islam arus global, dan faktor ini dapat melengkapi teori perubahan pendidikan Islam di Indonesia menurut Karel Steenbrink.
\end{abstract}

Keywords: Islamic Education, Pesantren Salafi Manhaj, education model

\section{Pendahuluan}

Di Indonesia, pendidikan Islam sudah ada sejak awal mula Islam masuk ke Nusantara. Secara tradisional pendidikan Islam itu disebut dengan 
pesantren. Selain itu juga ada istilah lainnya dengan pengertian sama yang menunjukkan lokalitas, misalnya dayah sebutan untuk daerah Aceh, surau untuk daerah Minangkabau, pesantren, pondok, langgar untuk daerah Jawa (Azra dkk., 2005:1-4). Kemudian dalam perkembangannya, pendidikan Islam mengalami penyesuaian dengan keadaan jaman dengan pengelolaan/sistem modern sehingga lahirlah sistem madrasah. Pesantren dan madrasah di Indonesia mempunyai karakter asli yang berbeda dengan pendidikan Islam di dunia. Dari awal mulanya hingga kini, pendidikan Islam di Indonesai selalu mengalami perkembangan dan pergeseran (Azra, 2012: 94-104). Termasuk munculnya pesantren model manhaj salafi, yang mana pesantren ini berbeda karakternya dengan pesantren-pesantren salaf maupun yang kholaf.

Menyoroti perkembangan pesantren manhaj salafi di Indonesia pada tiga dekade akhir ini terlebih setelah tumbangnya rezim orde baru adalah sangat cepat dan masif. Perkembangannya merupakan representasi dari dampak Islam arus global (gerakan salafis) yang tidak terlepas dari kontroversi dengan masyarakat sekitar. Masalah kontroversinya karena gerakan tersebut termasuk juga pesantren ber-manhaj salafi tumbuh berkembang dengan corak sebagai pendidikan Islam yang eksklusif yang kurang akomodatif dengan budaya masyarakat. Tumbuhnya gerakan salafi dan pesantren ber-manhaj salafi misalnya, munculnya Dewan Dakwah Islam Indonesia, Lembaga Ilmu Pengetahuan Islam dan Bahasa Arab (LIPIA), gerakan aktivis Islam kampus, berdirinya pesantren al-Irsyad Tangerang, dan lain sebagainya, yang sering berseberangan pandangan dan budaya dengan masyarakat. Munculnya gerakan tersebut berupaya mengembangkan ideologi manhaj salafi yang kurang akomodatif dengan kondisi sosio-kultur/sosio-historis masyarakat sehingga gerakan salafi ini kerap menimbulkan konflik masyarakat (Noorhaidi, 2005: 23-84).

Tumbuhnya gerakan tersebut, termasuk pesantren bermanhaj salafi, di sisi lain berbeda dengan penjelasan yang menyatakan bahwa pesantren sebagai lembaga pendidikan agama Islam yang akomodatif terhadap kondisi sosial budaya bangsa dan merupakan pendidikan yang memuat nilai-nilai multikultural (Irham, 2015: 93-118). Hal yang sama juga dijelaskan oleh Azra yang menyatakan bahwa pendidikan pesantren adalah untuk menjadikan manusia seutuhnya bukan bermaksud untuk menumbuhkan mental-mental manusia yang tertutup, yang tidak menerima keragaman atau yang suka berkonflik dan melakukan penyimpangan sosial (Azra, 2012: 4-9).

Artikel ini berupaya menguraikan perkembangan pesantren manhaj salafi di Indonesia dan atas faktor apa model pendidikan ini dapat berkembang. Artikel 
ini merupakan kajian tentang pendidikan agama Islam yang memfokuskan kajiannya terhadap perkembangan pesantren bermanhaj salafi. Dalam kajian ini metode yang digunakan adalah studi kepustakaan, yakni mengkaji pesantren yang bermanhaj salafi dengan menggunakan literatur hasil penelitian terkini. Sumber primer dalam penulisan artikel ini adalah laporan penelitian disertasi yang ditulis oleh Din Wahid di Universitas Utrecht Belanda yang selesai pada tahun 2014. Disertasinya berjudul "Nurturing The Salafi Manhaj: A Study of Salafi Pesantren in Contemporary Indonesia." Kemudian, sumber sekunder sebagai pendukung adalah hasil penelitian terkait tentang kepesantrenan dalam bentuk buku maupun jurnal.

Pentingnya menuliskan artikel ini adalah untuk mengetahui perkembangan terkini terkait dengan perubahan atau pergeseran pendidikan Islam di Indonesia. Secara khusus untuk menemukan perkembangan pesantren bermanhaj salafi di Indonesia. Temuan ini dapat mengetahui corak dan model pendidikan bermanhaj salafi yang telah diselenggarakannya, begitu pula corak keberagamaannya. Jadi, artikel ini menjawab pertanyaan besar, bagaimana perkembangan terkini model pendidikan Islam di Indonesia pada kasus pesantren yang bermanhaj salafi?

Dalam artikel ini yang menjadi sumber primer adalah disertasi Din Wahid yang berjudul "Nurturing The Salafi Manhaj: A Study of Salafi Pesantren in Contemporary Indonesia." Disertasi ini dikerjakan di Universitas Utrecht Belanda selesai pada tahun 2014 yang mengkaji tentang perkembangan keberagamaan manhaj salafi di Indonesia terutama dilihat dari lembaga pendidikan pesantren. Kajian dalam disertasi ini dapat melihat perkembangan terkini tentang gerakan salafi di Indonesia setelah kajiannya Noorhaidi tentang "Laskar Jihad Islam, Militancy and The Quest for Identity in Post-New Order Indonesia” tahun 2005. Disertasi Din Wahid menelusuri perkembangan keberagamaan akibat dari globalisasi Islam Timur Tengah yang bermanhaj salafi. Din Wahid memfokuskan penelitiannya pada pesantren salafi di Indonesia dan melihat kehidupan masyarakat/pengikut/penganutnya. Temuan-temuannya terkait dengan pertama, bagaimana ideologi yang dikembangkan di pesantren/ penganut salafi. Kedua, bagaimana internalisasi manhaj salafi terhadap santri, yaitu dengan menganalisis secara dinamis kehidupan santri di pesantren, seperti interaksi antara mudir (direktur), ustaz, dan santri. Kemudian interaksi antara penghuni pesantren dengan warga di luar pesantren. Ketiga, asal-usul sumber pendanaannya. Keempat, jaringan-jaringan yang dikembangkan dalam misi dakwah salafi. Kelima, praktik kehidupan masyarakat salafi dan keenam, 
bagaimana respon masyarakat lokal dengan adanya gerakan salafi.

Din Wahid dalam melakukan penelitian disertasinya menggunakan pedekatan antropologi. Pencarian data dilakukan selama 17 bulan yang terbagi dalam dua periode. Pertama pada bulan Agustus sampai bulan April 2009. Periode kedua pada bulan Desember 2009 sampai dengan September 2010. Pada periode pertama ada 14 pesantren manhaj salafi yang dikunjungi sebagai objek penelitian. Selanjutnya pada periode kedua mengerucut menjadi tiga pesantren. Ketiga pesantren tersebut adalah pesantren al-Nur al-Atsari Banjarmasin, Assunnah di Ceribon Jawa Barat dan al Furqon Sidayu Gresik Jawa Timur (Wahid, 2014b: 12-13).

Artikel ini lebih menyoroti temuan-temuan yang terkait dengan "reform in contemporary in Islamic education," sehingga yang menjadi fokus pembahasan dalam artikel ini bukan secara keseluruhan disertasi Din Wahid, namun dibatasi pada pembahasan yang berhubungan dengan pendidikan Islam yang dikembangkan oleh kelompok manhaj salafi, yaitu tentang ideologi manhaj salafi dan model pendidikan pesantren. Pembatasan ini tidak lain tujuannya untuk memfokuskan pembahasan tentang bagaimana ideologi kelompok manhaj salafi dan bagaimana model pendidikan Islam yang dikembangkannya. Dua hal ini selalu terkait karena ideologi yang memengaruhi dasar dikembangkannya lembaga pendidikan sehingga dapat ditemukan model baru pendidikan Islam di Indonesia atas dasar ideologi manhaj salafi.

\section{Dasar Ideologis Manhaj Salafi}

Ada tiga istilah yang berkembang di masyarakat Indonesia, namun secara akar kata sama artinya yaitu salaf, salafiyah, dan salafi. Akar kata ini dalam bahasa Arab adalah salafa yang artinya "mendahului." Secara maknawi dipahami sebagai salaf al shalih yakni tiga generasi sahabat Nabi yang awal. Tiga generasi ini terdiri dari sahabat Nabi, tabi'in, tabi'it-tabi' in. Kemudian istilah salafi, salaf, dan salafiyah dikaitkan dengan makna tersebut yaitu orang yang mengikuti jejak para salaf al-shalih. Dalam konteks keindonesiaan, istilah salaf, salafi dan salafiyah mempunyai makna yang mafhum yaitu kelompok muslim tradisional yang mempertahankan tradisi-tradisi lama. Hal ini terlihat seperti kalangan pesantren tradisional yang masih mempertahankan tradisi kitab kuning dan budaya-budaya lama. Kemudian dalam perkembangan terakhir ini ada istilah salafi yang dimaknai sebagai pengikut manhaj salafi (Wahid, 2014b: 17-53).

Manhaj berakar dari kata nahaja yang artinya metode atau proses. Adapun manhaj salafi adalah metode mengaplikasikan ajaran agama seperti 
yang diajarkan Nabi yang sesuai dengan apa yang telah dijalankan oleh tiga generasi awal penerus Nabi. Metode keberagamaan ini menjelma menjadi gerakan salafi/salafisme. Gerakan ini merupakan gerakan purifikasi ajaran Islam untuk kembali kepada sumber utama yaitu al Quran dan al Hadits secara praktik maupun keyakinan dalam menjalankan ajaran Islam. Purifikasi yang dimaksud adalah memurnikan ajaran Islam dari kesyirikan, bid'ah, khurafat, tahayul dan mitos. Hal yang sama juga dinyatakan oleh Duderija bahwa salafi sebagai gerakan atau model keberagamaan yang ingin seperti keberagamaannya tiga generasi awal setelah nabi, terkait dengan identitas, keyakinan, perilaku dan seterusnya. Dia menyebutnya dengan istilah 'neo tradisional salafi' (Duderija, 2014: 341-363).

Gerakan dan para pengikut salafi wajib untuk menjalankan praktik keagamaan bermanhaj salafi. Manhaj ini sebagai sumber ketiga setelah al Quran dan al Hadits. Manhaj ini merujuk pada karya tokoh besar Ibnu Taimiyah dan Muhammad bin Abdul Wahhab yaitu kitab al aqdu al wasathiyah, kitab al tawhid, dan ushul al thalatha. Kemudian di era kontemporer tokoh yang menjadi rujukan adalah Abdul Aziz Ibnu Baz dan Muhammad Nasir al Dini al Albani.

Prinsip dan karakter dasar manhaj salafi bertumpu pada akidah. Menurut manhaj ini, akidah sangat esensial dari pada misalnya fikih. Karena dengan akidah yang benar menjadikan muslim sangat mulia. Prinsip dan karakter dasar ini tercakup dalam tawhid, mengikuti jejak sunnah, menentang terhadap bid'ah, al-wala' wal bara' dan taat terhadap penguasa.

Dalam tawhid perinciannya ada empat macam. Pertama tawhid rububiyyah, tawhid ini artinya kepercayaan terhadap Tuhan yang esa yang menciptakan alam semesta. Namun dengan hanya pengertian seperti ini bagi seorang muslim belum cukup. Maka harus bertumpu pada tawhid selanjutnya; kedua tawhid uluhiyyah. Tawhid ini representasi dari pengakuan Islam la ilaha illa Allah, yakni meyakini adanya Tuhan yaitu Allah dan menjalani ibadah hanya untuk Allah; ketiga, tawhid al-asma wal-sifat. Tawhid ini merupakan keyakinan atas asma dan sifat Allah dengan memahami secara literal tanpa ada unsur ta'lil, tahrif, takyif, tashbih dan tafwid; keempat, tawhid mulkiyya/hakimiyya. Tawhid ini meyakini bahwa Tuhan adalah satu-satunya penguasa di dunia ini. Keberadaan manusia di bumi adalah hanya merumuskan kembali untuk menjalankan dan menentukan apa yang ada di dalam al Quran dan contoh dari Nabi. Sebenarnya tawhid keempat ini sebagai tambahan dari kelompok salafi jihadi. 
Kemudian cakupan selanjutnya adalah mengikuti sunnah Nabi. Sunnah dimaknai sebagai jalan/metode keberagamaan yang benar yakni pemahaman dan praktik keagamaan yang sesuai dengan Nabi dan pengikutnya (tiga generasi awal). Pernyataan yang paling menggambarkan hal ini adalah 'Islam adalah sunnah dan sebaliknya sunnah adalah Islam' (Wahid, 2014b: 28). Kebalikan sunnah adalah bid'ah, artinya adalah menciptakan model keberagamaan baru yang tidak sesuai dengan apa yang dipraktikkan oleh Nabi, bahkan secara berlebihan. Bid'ah ada dua, pertama bid'ah secara esensial maksudnya, bid'ah yang tidak berbasiskan pada al Quran, al Hadits, ijma', dan pendapat ulama. Bid'ah tipe ini misalnya, menerima wahyu setelah Nabi Muhammad. Selanjutnya bid'ah yang kedua yaitu bid'ah tambahan, yakni praktik bid'ah yang berargumentasi sesuai dengan al Quran dan al Hadits namun nyatanya tidak sesuai. Dalam praktiknya makna bid'ah di atas dibagi menjadi bid'ah i'tiqadiyah dan bid'ah 'amaliyah.

Aspek lain yang termasuk dalam tawhid adalah konsep al wala' wal bara'. Maksud dari konsep ini yaitu upaya mencintai dan membenci hanya untuk membela kepentingan Allah, misalnya al wala' mencintai dan selalu membantu sesama muslim yang baik dan selalu mempertahankan kepentingan-kepentingan Islam. Berikutnya al bara' adalah mengutuk terhadap orang kafir atau yang merusak dari jalan Islam. Singkatnya adalah upaya untuk selalu menjaga dari kerusakan/kecurangan dari orang kafir.

Aspek selanjutnya adalah ketaatan terhadap penguasa. Aspek ini sebagai aspek tambahan bagi sebagian kecil kelompok salafi. Sebagian besar lainnya tidak menerapkannya. Konsep ketaatan penguasa sangat penting terkait dengan sikap muslim terhadap pemerintah. Landasan doktrin untuk konsep penguasa ini ada pada al Quran (4:59) tentang ketaatan kepada ulil amri. Hal ini sebagai kewajiban dan dapat mengabaikannya jika dengan argumentasi yang kuat yang sesuai dengan kepercayaan agama.

Di Indonesia, munculnya gerakan manhaj salafi era kontemporer ini merupakan bagian dari globalisasi salafisme dari pemerintah Arab Saudi. Ideologi salafi ini dengan sengaja di ekspor oleh Arab untuk muslim dunia. Beberapa upaya yang dilakukan untuk itu adalah pemberian beasiswa pendidikan ke Arab, pembangunan masjid, publikasi buku, majalah, membangun lembaga pendidikan Islam, dan mengembangkan pengajaran salafi. Pola yang digunakan dalam pengembangan ini melalui jaringan, mengembangkan kelompokkelompok, dan lembaga-lembaga pendidikan dengan didukung pendanaan yang besar dari Timur Tengah, terutama untuk keberadaan yayasan ataupun 
lembaga pendidikan Islam. Termasuk juga penguatan jaringan dakwah, misalnya, melalui media cetak, radio, internet, dan publikasi buku serta melalui kelompok-kelompok seperti jamaah pengajian di masjid.

Gerakan salafi di Indonesia bukan semata tumbuh dengan sendirinya dari masyarakat. Melainkan dari gerakan yang mendapat dukungan pendanaan yang kuat. Sumber pendanaan tersebut ada tiga, yakni sumber internasional, sumbangan yayasan, dan sumbangan individu. Sumber internasional itu misalnya, Kuwaiti Charitable Foundation, Jamiyyat Ihya' al Turast al Islam, The Qatari Sheikh Eid Charity Foundation (Wahid, 2014b: 96-97).

Gerakan salafi di Indonesia terbagi menjadi tiga tipe. Pertama, tipe salafi puris; kedua, salafi haraki; ketiga, salafi jihadi; ketiga tipe tersebut dapat dibedakan melalui sikap mereka terhadap penerimaan atau penolakan kebijakan pemerintah. Di Indonesia, tipe salafi yang dominan adalah salafi puris. Gerakan ini selalu menyuarakan kembali pada al Quran dan al Hadits. Kemudian menjahui praktik-praktik keagamaan yang berbau syirik, bid'ah, khurafat, dan tahayul. Gerakan ini tergolong menjadi tiga, yakni rijeksionis, kooperatif dan tanzimi. Gerakan rijeksionis lebih eksklusif. Gerakan ini menolak untuk berorganisasi maupun berpartai. Kemudian gerakan salafi yang kooperatif karakternya lebih inklusif, yakni terbuka dengan masyarakat muslim di luar dari kelompoknya, bergabung dengan partai, dan menerima kebijakan pemerintah. Dan tipe salafi tanzimi sebagai salafi yang berbentuk ormas. Seperti Wahdah Islamiyyah dari Makassar Sulawesi Selatan dan Harakah Sunniyah untuk Masyarakat Islam (HASMI) dari Bogor Jawa Barat (Wahid, 2014b: 35-44).

Berikutnya tipe salafi haraki. Kelompok tipe ini selain purifikasi ajaran Islam juga tidak sepaham dengan ideologi negara yang tidak syariat Islam. Namun, salafi haraki tidak melakukan penyerangan-pemberontakan, hanya sekedar pergerakan pemikiran. Gerakan haraki ini selangkah lagi dapat menjadi tipe yang ketiga. Selanjutnya tipe ketiga yaitu salafi jihadi yang merupakan kelompok salafi sama dengan tipe haraki, perbedaannya salafi jihadi melakukan pemberontakan/penyerangan yang menurut mereka salah. Seperti melakukan pemboman (radikalisme) dengan atas nama jihad menegakkan negara yang berdasar syariat agama, memerangi orang kafir, syirik dan seterusnya.

Tipologi keberagamaan salafi tersebut yang terbagi menjadi tiga tidak terlepas dari pola doktrinasi agama yang diterapkan. Adis Duderija dalam hal ini sepakat menyatakan bahwa pola pemahaman ajaran agama oleh kelompok salafi sangat tekstualis sehingga keberagamaan yang terlahirkan 
menjadi fundamental. Duderija menyebutnya kelompok penganut manhaj salafi dengan istilah neo-traditional salafism (Duderija, 2010: 75-93). Model keberagamaan yang seperti itu juga ditemui oleh kelompok salafi di negara lain. Misalnya di Swedia, ideologi memurnikan Islam selalu ditekankan. Bahkan di sana kecenderungannya adalah eksklusif. Orang yang tidak sesuai dengan prinsipnya tidak dianggap dalam kelompoknya walaupun sesama muslim (baca Olsson, 2012: 71-92).

Strategi penyebaran/pengembangan gerakan salafi melalui tigal hal yakni, pengembangan jaringan dakwah, pengembangan kelompok-kelompok, dan pengembangan institusi pendidikan seperti pesantren. Pengembangan jaringan dakwah yang dilakukan adalah menyuarakan dakwah salafi melalui radio, TV, majalah, publikasi buku, media sosial, koran dan media internet. Kemudian pengembangan kelompok/jamaah salafi seperti membuat organisasi, partai, dan jamaah pengajian. Selanjutnya pengembangan lembaga pendidikan dengan mendirikan pesantren-pesantren salafi, sekolah terpadu, perguruan tinggi seperti LIPIA.

\section{Pesantren Wadah Gerakan Manhaj Salafi}

Pertama kali yang mendirikan pesantren di Indonesia adalah Sunan Ampel yang berada di daerah Ampel Surabaya, lalu berkembang ke seluruh penjuru Nusantara. Perkembangan pesantren ini melalui santri-santrinya yang sudah dianggap lulus dan mendirikan pesantren di tempat lain hingga akhirnya tersebar di pejuru Indonesia (Azra, 2013: 11-12). Pesantren adalah sebagai lembaga pendidikan agama Islam. Ada lima elemen dasar yang membentuknya, yang terdiri dari pondok, masjid, kyai, santri dan kitab kuning. Kyai menjadi tokoh sentral yang mengendalikannya dari segala aspek kepesantrenan. Kemudian pesantren sebagai transmisi faham aswaja oleh para kyainya (Dhofier, 2011: 79-99).

Kitab kuning di pesantren menjadi tradisi yang sangat kuat. Tradisi ini kuat tidak lain karena untuk transmisi keilmuan Islam tradisional yang ditulis ulam-ulama terdahulu. Pembelajaran melalui kitab kuning ini ada tahapannya/ strukturnya dari level yang paling sederhana sampai pada yang paling rumit, baik kitab fikih, tauhid, tasawuf, Hadits, tafsir dan seterusnya. Di pesantren juga dikenal dengan tradisi sanad/ketersambungan keilmuan dari guru ke guru hingga tersambung sampai pada guru yang tertinggi. Jadi, para santrikyai sangat jelas jaringan keilmuannya (Bruinessen, 1995: 17-21). Gambaran dasar ini berbeda dengan pesantren yang berkembang oleh kelompok manhaj 
salafi, yang mana bukan mentransmisikan faham aswaja dari kyai-kyai dan tradisi-tradisi lama melainkan mentranmisikan manhaj salafi.

Tak ubahnya seperti pesantren-pesantren pada umumnya, pesantren salafi sebagai tempat pendidikan agama Islam, lebih khusus sebagai pusat pengembangan model keberagamaan ber-manhaj salafi. Pesantren yang dikembangkannya mulai dari level pra sekolah (PAUD-TK) sampai pada level pendidikan tinggi. Ada empat jenis program pendidikan yang dikembangkan dalam pesantren, pertama program tahfidh al Quran (menghapal al Quran), kedua program tadrib al-duat (pelatihan mengajar), ketiga program tarbiyatun nisa' (pendidikan wanita).

Ada dua model pesantren yang dikembangkan. Pertama, model pesantren eksklusif, yaitu pesantren yang hanya mengembangkan ilmu pengetahuan Islam dan ditambah sedikit pengetahuan umum yang dasar yaitu pelajaran bahasa Indonesia dan matematika. Pengetahuan umum dasar hanya sekedar memberikan bekal pengetahuan dalam berinteraksi kepada masyarakat, dan selebihnya tidak. Model pesantren yang seperti ini dikembangkan oleh kelompok salafi puris yang eksklusif (puris rijeksionis). Model yang kedua yaitu pesantren yang cenderung inklusif. Pesantren ini selain mengajarkan ilmu-ilmu Islam juga ilmu-ilmu umum dengan mengadopsi kurikulum Nasional. Pesantren model ini dikembangkan kelompok salafi puris yang kooperatif.

Salah satu contoh yang eksklusif adalah pesantren al Furqon Gresik. Pesantren ini mempunyai jenjang pendidikan mulai dari TK-tahfidh, mutawassitah, tsanawiyah, takhassus dan pendidikan tinggi. Pesantren ini untuk tahfidh al Quran dan mempelajari pengetahuan agama dasar seperti akidah, akhlak, Hadits, dan fikih. Adapun pengetahuan umum dasar yang dipelajari terdiri dari pengetahuan alam dan sosial, matematika, bahasa Indonesia, dan pendidikan kewarganegaraan. Buku panduan yang digunakan seperti dalam kurikulum nasional. Pesantren ini tidak mengikuti ujian nasional, namun jika santrinya ingin mendapatkan pengakuan secara resmi diijinkan untuk mengikuti kejar paket (Wahid, 2014b: 161-163).

Pengajaran manhaj salafi di pesantren dimulai sejak dini. Misalnya di TK, model penerapannya dengan mengajarkan doktrin salafi yang paling dasar. Misalnya, mengingat macam-macam ibadah yang penting yang berdasar atas Hadits Nabi, melarang anak menggambar makhluk hidup (manusia dan hewan), melarang anak menyanyikan lagu, dan memisahkan perempuan dari laki-laki dengan kelas yang berbeda. Guru yang mengajar anak-anak itu adalah seorang wanita yang bercadar namun ketika dalam kelas cadarnya dibuka. 
Untuk program pelatihan pengajaran diperuntukkan kepada siswa yang berusia belasan ke atas atau siswa dewasa terlebih yang senior. Tujuan program ini agar siswa mampu mengajarkan atau menyebarkan pengetahuan yang dimiliki kepada orang lain. Program ini tidak terbatas pada kurikulum, waktu atau tempat tertentu. Dapat dilakukan kapan saja sesuai dengan kondisi yang sesuai. Karena semua santri tinggal di pesantren, sehingga menjadi fleksibel. Kurikulum tergantung dan ditentukan dari guru yang bertanggungjawab. Biasanya dalam pengajaran ini satu guru memberikan satu sampai tiga pembahasan dengan menggunakan satu pedoman buku. Metode yang digunakan adalah mulazama, yaitu santri berkumpul dan mendengarkan guru berceramah atau menjelaskan pembahasan dalam buku pedoman. Metode ini sama dengan yang diterapkan pesantren tradisional yang biasa disebut dengan bandongan/wetonan. Metode ini santri mendengarkan uraian-uraian kyai terhadap penerjemahan atau eksplorasi penjelasan kitab yang dibaca (Dhofier, 2011: 54).

Selanjutnya program pendidikan wanita (tarbiyah al-nisa') merupakan program yang diperuntukkan kaum wanita. Tujuannya adalah mepersiapkan siswa perempuan untuk menjadi istri yang dapat mendukung suaminya nanti dalam mendukung dan mengembangkan salafisme. Materi yang esensial sebagai bahan kajian adalah hubungan antara suami dan istri, secara khusus merujuk pada kitab Syaikh Muqbil yang berjudul Nasiha lil al Nisa'. Selain itu, mereka juga diajari keterampilan lain seperti memasak dan jahit-menjahit. Untuk mendapatkan pemahaman atau isu-isu baru tentang keperempuanan, pesantren menyediakan majalah, misalnya majalah assunnah yang secara khusus menyediakan pembahasan tentang keperempuanan, seperti adanya rubrik syakhsiah (personality), baytuna (our home), majalah fatawa yang di terbitkan oleh Bin Baz Center yang menyediakan rubrik keluarga sakinah (harmonious family), majalah al mawaddah yang diterbitkan pesantren al Furqon, dan masih banyak lainnya. Penjelasan bentuk pendidikan mannhaj salafi ini tidak jauh berbeda seperti yang disebutkan dalam disertasinya Noorhaidi, misalnya tentang penjelasan jaringan pesantren Ihyaus Sunnah Degolan Kaliurang Yogyakarta (Noorhaidi, 2005: 84-89).

Sama halnya dengan model seperti di atas, pesantren yang dikembangkan oleh kelompok salafi puris kooperatif lebih inklusif. Bentuknya adalah pesantren mengelola pendidikan formal yang lebih profesional, misalnya pendirian sekolah Islam terpadu (IT). Mulai pada level pra sekolah hingga perguruan tinggi, yakni TK Islam terpadu (TK IT), SD IT, SMP IT, SMA IT, dan pendidikan tinggi ( $\mathrm{ma}^{\prime} \mathrm{had}$ ' ali). Materi pendidikan TK IT-SMA IT adalah 
mengacu pada kurikulum pendidikan nasional dan pengajaran doktrin manhaj salafi. Selanjutnya pada tingkatan pendidikan tinggi ialah siswa yang lulus dari SMA. Pendidikan tingginya didesain dalam periode dua tahun dengan menerima 10 siswa dalam satu tahun. Tahun pertama pelajaran yang diterima adalah bahasa arab, ilmu alat (Nahwu dan Sharf), pengetahuan agama, dan manhaj salafi. Pada tahun kedua praktik dakwah. Setelah lulus siswa dapat melanjutkan ke LIPIA Jakarta.

Awal ide pendirian sekolah terpadu terinspirasi dari ide Hasan al Banna pendiri Ikhwanul Muslimin dari Mesir yang telah membangun gagasan "generasi rabbani" (generasi yang dengan penuh kesadaran atas keberadaan Tuhan sang pencipta alam semesta). Al Banna meyakini generasi ini akan terwujud dari proses pendidikan yang panjang. Ide ini berkembang di Indonesia sejak bertemunya pelajar Indonesia pada tahun 80-an hingga sekarang dengan gerakannya tarbiyah Islamiyah dari kampus hingga mendirikan sekolah terpadu Nurul Fikri di Bandung yang selanjutnya menjelma/bermetamorfosis menjadi Partai Keadilan sekarang berubah menjadi Partai Keadilan Sejahtera (PKS).

\section{Kurikulum Manhaj Salafi}

Seperti dalam penjelasan sebelumnya, bahwa model pesantren salafi ada yang inklusif dan ada yang eksklusif. Yang membedakan dua model ini adalah terkait dengan sistem kurikulum yang digunakan. Pesantren inklusif yang berafiliasi salafi puris kooperatif mengadopsi secara penuh kurikulum nasional dan mengikuti ujian nasional. Selain itu, pesantren model ini juga mengadopsi kurikulum Arab Saudi dalam pengetahuan keislaman. Hal ini untuk mendapatkan akreditasi dari Universitas Arab Saudi dan Universitas Islam Medina. Pentingnya akreditasi itu untuk mendapatkan pendanaan dari Timur Tengah, misalnya dari Charitble Foundations dari Timur Tengah, Jamiyya Ihya' al Turath dari Kuwait, dan Muassasat Aid al Thani dari Qatar.

Kurikulum model yang kedua yang berafiliasi pada salafi rijeksionis mengacu pada kurikulum Sheikh Muqbil di Dammaj Yaman, terkait dengan model pembelajaran, materi, dan metodenya. Fungsi dari pesantren model ini sama dengan peran pesantren yang pada mulanya yakni, transmisi pegetahuan agama, menjaga tradisi Islam, dan melahirkan ulama yang tentunya dalam hal ini bermanhaj salafi. Adanya hubungan dengan Timur Tengah dalam hal kurikulum ini tidak lain berorientasi untuk melanjutkan ideologi salafi dan secara pragmatis mendapatkan pengakuan dan finansial dari Timur Tengah.

Pesantren salafi memprioritaskan pada kajian akidah. Kemudian buku 
rujukan/kitab yang menjadi pedoman dasar sebagai materi pembelajaran adalah kitab yang ditulis oleh Muhammad bin Abdul Wahhab yang berjudul al Usul al Thalatha, Kitab al Tawhid, Kashf al Shubuhat, Masail al-Jahiliyah, dan syarahnya yang ditulis oleh para sarjana salafi seperti Muhammad Ibnu Salih al Uthaymin dan Salih Ibnu Fawzan ibnu Abd Allah al Fauzan. Ditambah juga kitab yang ditulis oleh Ibnu Taymiyyah yang berjudul al Aqida al Wasitiyyah dan syarahnya yang ditulis oleh al Uthaymin yang berjudul Sharh al 'Aqida al Wasitiyyah dan al 'Aqida al Tahwiyyah oleh al-Imam al Tahawiyyah dan di syarahi oleh Ibnu Abi al 'Izzi.

Setelah kajian akidah sebagai prioritas yang pertama, yang kedua adalah Hadits. Kitab-kitab Hadits yang digunakan hampir sama dengan yang digunakan pesantren pada umumnya misalnya, al-Arbain Nawawi, Shahih Bukhori dan Shahih Muslim. Namun, perbedaannya terletak pada otoritas penggunaan kitab dan syarahnya yang dipegang oleh sarjana salafi. Selain Hadits adalah kitab fikih karya dari Abd al 'Azim ibnu Badawi yang berjudul al Wajiz fi Figh al Sunna wa al Kitab al 'Aziz, kitab karya Ibnu Qudama 'Umdat al Ahkam yang disyarahi lagi ke dalam kitab Taysir al 'Allam oleh Abd Allah ibnu Abd al Rahman ibnu Salih Alu Bassam. Kitab akhlak yang dikaji menggunakan al Ta'lim al Muta'allim oleh al Zarnuji dan sejarah Islam menggunakan kitab Khulasah Nur al Yaqin karya Umar Abd al Jabbar.

Baik kajian akidah, Hadits, fikih maupun akhlak kitab kesemuanya langsung dikirim dari Arab. Terbukti bahwa kita-kitab yang digunakan mengajar itu terbitan dari Wazarat al-Maarif (kementerian Pendidikan) Saudi Arabia. Dalam menerapkan doktrin manhaj salafi, pesantren membuat tahaptahapan/struktur keilmuan. Pada bidang akidah untuk tingkatan ibtidaiyah yang dipelajari adalah kitab Usul al Thalatha. Materi pertama yang dipelajari adalah tentang masail al arba' yang mengkaji tentang pengetahuan (ilmu), bagaimana mengimplemtasikannya, apa yang dapat dikategorikan sebagai ilmu dan bagaimana cara mendakwahkannya.

Pada kajian tentang ilmu ada tiga pokok dasar/prinsip pembahasan. Prinsip itu adalah ilmu tentang ketuhanan, bahwa Allah lah yang wajib disembah, yang kedua prinsip ilmu tentang beragama (iman, Islam dan ihsan), dan tentang pesan Nabi Muhammad. Metode belajar untuk ini sangat sederhana, seperti memberikan penjelasan secara singkat dan padat, mendefinisikan, mengikuti dalil dari al Quran dan al Hadits dan dalam memberikan contoh masalah, metode yang digunakan dengan cara berdialog, ada pertanyaan dan ada jawaban. Pada level mutawasitah/tsanawiyah kitab yang digunakan adalah 
kitab tawhid karya Muhammad Abdul Wahhab yang mengkaji tentang tawhid al-uluhiyyah, al-rububiyyah, dan asma wa al-sifat. Namun secara detil kitab ini dibahas pada tingkatan aliyah karena pada tingkat tsanawiyah kitab yang dikajimasih bersifat dasar.

Bidang kajian selanjutnya yaitu Hadits. Pelajaran Hadits masih terkait dengan tawhid. Keduanya terintegrasi karena Hadits diberikan untuk memberikan penguatan terhadap pemahaman tawhid, misalnya saja hadis tentang kesyirikan, kekafiran, bid'ah dan seterusnya. Sebelumnya juga dibahas tentang biografi singkat perawi Hadits. Tujuan ini untuk mengetahui perawi siapa yang sempurna dan patut dijadikan pegangan dan yang tidak sempurna tidak boleh digunakan. Pada bidang fikih, pembahasannya tidak jauh beda pada fikih yang lain. Misalnya tentang bersuci/toharoh, salat, zakat, haji, dan muamalah. Kitab-kitab fikih yang digunakan sesuai dengan ketentuan manhaj salafi, dan tidak lebih dari itu.

Membumikan manhaj salafi kepada santri bukan hanya melalui pembelajaran saja melainkan praktik hidup keseharian. Upayanya adalah melakukan pembiasaan-pembiasaan di dalam tradisi pesantren. Pembiasaan tersebut mulai dari cara berpakaian hingga pada prinsip hidup, seperti halnya pelarangan bermain, menonton atau mendengarkan segala alat musik, bernyanyi, menonton tv, dan mendengarkan radio. Hal itu dinilai sebagai perkara bid'ah, haram untuk dilakukan. Selain itu kesenian teater dan drama juga dilarang sebab dinilai sebagai imitasi dari budaya non muslim.

Manhaj salafi lebih menekankan dan meyakini metode dakwah yang tawqifi bukan merupakan ijtihadi. Sehingga tidak ada ruang lagi untuk berbeda pendapat. Pembiasan lainnya terdapat dalam bentuk berpakaian ala salafi (Wahid, 2014b: 225). Ada empat identias pakaian salafi yang diterapkan yaitu jalabiya, isbal, lihya, dan niqab. Berikutnya pemberian nama sebagai nama alias dengan bahasa arab. Misalnya anak laki yang bernama Fauzan dijuluki Abu Fauzan, begitu pula untuk perempuan dengan julukan Umi. Pemanggilan ini dinilai sunnah dan berarti sebagai doa. Nama alias ini sebagai nama non formal saja karena secara administratif nama asli yang tetap dipakai. Dalam hal makan dan minum dibiasakan seperti perintah nabi yaitu dengan tangan kanan, pakai tiga jari, dan duduk bersama-sama.

Kehidupan pesantren salafi yang puris kooperatif bukan pasif dan statis, melainkan aktif dan dinamis. Mereka merespon perubahan keadaan yang dibutuhkan pada masa sekarang. Seperti halnya respon terhadap perubahan kebijakan pendidikan nasional, termasuk metode pembelajaran atau materi 
pengajaran dan lain sebagainya. Melihat respon ini, dapat diketahui seberapa jauh pesantren salafi dalam menghadapi tantangan zaman. Khususnya terkait dengan pengembangan gerakan salafi.

Siswa yang sekolah di pesantren salafi pun beragam. Ada yang memang dari keluarga salafi dan ingin anaknya menjadi salafi yang kaffah. Adapula yang berlatar belakang dari keluarga non salafi. Siswa yang berlatar belakang non salafi sejatinya tidak ingin menjadi anaknya salafi, melainkan motifnya adalah karena pendidikan yang diselenggarakannya bagus dan profesional. Kedua, menghindarkan anak dari pergaulan yang bebas dan tercela. Karena orang tua yang sibuk dan tidak sempat mengasuhnya sehingga di sekolahkan di lembaga salafi karena sistemnya full day. Dan ketiga, menjadikan muslim yang baik.

Pergerakan salafi di Indonesia menemui pertentangan bagi masyarakat sekitar. Terutama masyarakat NU. Warga NU sangat menolak tegas dengan gerakan-gerakan salafi baik secara lisan maupun aksi. Seperti halnya penolakan salafi terhadap perilaku warga NU yang dianggap sesat. Misalnya, kegiatan tahlilan dan selametan yang di anggap bid'ah dan sesat. Berbeda dengan kelompok Persis dan Muhammadiyah, kelompok ini cenderung menerima secara positif karena mempunyai misi yang sama yaitu sama-sama menolak aktifitas bid'ah, syirik, takhayul, dan khurafat.

Walaupun kelompok salafi banyak ditentang oleh masyarakat maupun tokoh agama setempat, mereka masih tetap kuat. Pesantren salafi masih berjalan hingga sekarang karena tangguhnya kelompok salafi dalam memegang manhaj salafi serta militansinya dalam memegang dan menyebarkan salafisme sehingga nampak dalam hidupnya seakan tercurah untuk pengabdian mengembangkan manhaj salafi, selain karena didukung finansial yang kuat (Wahid, 2014b: 275).

\section{Manhaj Salafi: Islam Arabi}

Karel A. Steenbrink, seorang antropolog dari Belanda banyak menyinggung tentang perkembangan pendidikan Islam di Indonesia, menguraikan perubahanperubahan dari pesantren ke madrasah dan juga ke sekolah dari segi materi, motode pembelajaran hingga dari kyai ke dokterandes/sarjana. Steenbrink mengungkapkan bahwa perubahan pendidikan Islam di Indonesia karena dipengaruhi atas dorongan/faktor perubahan umat Islam itu sendiri. Menurutnya ada empat faktor sebagai pendorong (Steenbrink, 1994: 26-34).

Faktor pertama pendorong tersebut adalah karena adanya dorongan 
umat Islam untuk purifikasi ajaran Islam dan menolak atas perilaku taklid. Sehingga, atas dasar ini perlunya umat Islam untuk kembali kepada al Quran dan al Hadits. Dorongan ini berawal dari pemikiran Muhammad Abduh dari Mesir beserta murid-muridnya. Faktor yang kedua ialah karena adanya nasionalisme masyarakat Islam untuk melawan/memberontak atas kekejian kolonial Belanda/penjajah. Faktor ketiga atas dorongan memperkuat pada bidang sosial dan ekonomi, baik untuk kepentingan organisasi umat Islam maupun untuk kepentingan umat Islam secara keseluruhan. Adapun faktor yang keempat adalah karena umat Islam tidak merasa puas dengan adanya pendidikan Islam yang ada terbatas dan belum mampu merespon perkembangan jaman.

Kerangka di atas sepertinya perlu ditambah lagi dewasa ini, terlebih ketika menganalisis kasus pesantren yang bermanhaj salafi seperti yang sudah disebutkan di atas terutama temuan-temuan dalam disertasinya Din Wahid. Pada faktor pertama, Steenbrink menyebutkan purifikasi sebagai pendorong perubahan dan juga karena menolak model keberagamaan yang taklid. Barangkali faktor pertama ini yang mungkin ada kesamaan dengan adanya gerakan pesantren manhaj salafi. Ketiga faktor setelahnya nampaknya tidak dapat menjadi alasan sebagai pendorong yang melatarbelakangi berkembangnya kelompok bermanhaj salafi. Namun pertanyaannya apakah benar murni atas dorongan purifikasi dan menolak taklid sebagai pemicu pesantren bermanhaj salafi?

Adanya kesamaan misi purifikasi tidak dapat dipungkiri. Upaya untuk kembali kepada al Quran dan al Hadits juga menjadi prioritas. Namun masyarakat salafi tidak menolak taklid. Bahkan manhaj salafi melarang berijtihad dan menekankan pada metode tawqifi, artinya taklid itu harus. Mereka menjadikan manhaj salafi sebagai sumber ketiga setelah al Quran dan al Hadits. Jadi, adanya pembaharuan pendidikan Islam di Indonesia dalam kasus pesantren bermanhaj salafi tidak dapat dikaitkan dengan kerangka Steenbrink.

Faktor pendorong keberadaan pesantren salafi di Indonesia yang paling jelas adalah karena adanya upaya globalisasi Islam Timur Tengah. Upaya tersebut sangat terstruktur. Hal ini dapat dibuktikan dengan argumentasi, pertama pemberian beasiswa terhadap umat Islam Indonesia oleh Arab Saudi untuk bersekolah di sana. Upaya ini sangat jelas yaitu mengkader umat Islam Indonesia mengamalkan dan menyebarkan manhaj salafi; kedua, pendanaan yang mengalir dari Arab Saudi untuk keperluan pengembangan jaringan dakwah dan pendidikan; ketiga, pesantren yang bermanhaj salafi menggunakan kurikulum dan bahan ajar dari Arab Saudi. Bahkan segala buku pedoman atas 
terbitan dari kementerian pendidikan Arab Saudi. Setidaknya atas tiga hal ini menjadi alasan yang sangat kuat untuk mengatakan pesantren bermanhaj salafi bukan atas dasar internal masyarakat Islam Indonesia. Melainkan untuk membangun keberagamaan Islam ala Arab Saudi.

Keberagamaan manhaj salafi berbeda dengan Islam lokal yang sudah lama berkembang. Melihat sejarah perkembangan Islam di Indonesia, dan dapat ditinjau dari sudut pandang sosiologis maupun antropologis, bahwa karakter Islam Indonesia adalah wasatiyah. Karakter ini menunjukkan bahwa Islam Indonesia sangat harmonis dengan kebudayaan. Wataknya adalah ramah, terbuka, toleran, adil, seimbang dan moderat (Aqiel Siradj, 2007: 74-79). Hal ini terbukti ketika kelompok nasionalis dan kelompok Islamis menyusun dasar ideologi negara Indonesia, yang terjadi bukan ideologi Indonesia sebagai negara sekuler dan bukan negara agama berasas Islam, namun berasas Pancasila. Asas ini sebagai kalimatun sawa, sebagai prinsip-prinsip yang sama di antara anak-anak bangsa yang majemuk dalam segala aspek kehidupan (Azra, 2015: 1-12). Dari tipologi keberagamaan salafi yang sudah dijelaskan sebelumnya, bahwa seakan keberagamaan salafi kontradiktif terhadap karakter Islam yang sudah lama berkembang di Indonesia sebagai Islam wasatiyah.

Berkembangnya kelompok salafisme di Indonesia menunjukkan munculnya kembali konservatisme. Kelompok ini menolak penafsiran ulang atas ajaran-ajaran Islam secara liberal maupun progresif. Kecenderungannya mempertahankan tafsir dan sistem sosial yang baku. Dua hal yang memicu menguatnya kelompok ini. Pertama adalah menguatnya arus demokrasi yang dikaitkan dengan memudarnya Islam liberal di Indonesia. Kedua menguatnya pengaruh Timur Tengah. Kecenderungan konservatisme ini bukan hanya datang dari kelompok salafi saja, melainkan juga dari ormas Islam yang sudah mapan, seperti MUI dan Muhammadiyah (Wahid, 2014a: 375-390).

Gerakan yang hampir serupa dengan manhaj salafi di Indonesia terwujud beragam sekali. Pemaparan di atas merupakan gerakan salafi pada era kontemporer ini yang berbeda pada era sebelumnya. Dalam sejarah bangsa Indonesia sendiri, gerakan serupa itu berbentuk partai dan juga ormas Islam seperti, DI TII, NII, Masyumi, Muhammadiyah, dan Persis. Namun pada akhirnya mereka melebur dengan kebudayaan masyarakat lokal. Bahkan yang secara terang-terang menolak ideologi Negara seperti NII dan semisalnya tidak bertahan lama dan runtuh sebelum berkembang. Inilah seperti dikatakan di atas adanya kontradiksi dengan karakter yang sebenarnya. Apakah nasib gerakan manhaj salafi akan sama seperti itu ataukah mampu jaya dan menjadi 
mayoritas di negeri Indonesia ini? Yang paling dapat diprediksikan adalah ketika manhaj salafi mampu berakomodasi dengan budaya lokal dan berkarakter Islam wasatiyah akan dapat eksis dan berkembang. Jika tidak, akan sebaliknya.

\section{Simpulan}

Dari pemaparan di atas, artikel ini dapat menyimpulkan lima hal: pertama, pesantren bermanhaj salafi berbeda dengan pesantren yang sudah lama berkembang di Indonesia, seperti pesantren salaf, salafiyah, salafi maupun yang kholaf; kedua, pesantren bermanhaj salafi mempunyai jaringan yang kuat dari Timur Tengah; ketiga, pesantren salafi melahirkan tiga tipologi keberagamaan santri. Tiga tipologi itu adalah tipe salafi puris (rijeksionis, kooperatif, dan tanzimi), kemudian tipe salafi haraki, dan tipe salafi jihadi. Ketiga tipe ini menunjukkan bahwasanya kelompok salafi coraknya adalah beragam, bukan hanya satu yang dikenal sebagai corak keberagamaannya fundamental-radikal. Keempat, model pesantren manhaj salafi terbagi menjadi dua, yaitu model eksklusif dan model inklusif. Model eksklusif adalah pesantren yang tidak menerima kurikulum umum/nasional kemudian model yang inklusif menerima kurikulum nasional dan mau mengikuti ujian nasional. Kelima, pesantren model manhaj salafi sebagai model baru pendidikan Islam di Indonesia dan dengan pemicu baru. Jadi, dengan adanya pesantren model manhaj salafi menunjukkan bahwa pemicu berkembangnya pesantren ini karena faktor globalisasi Islam Timur Tengah, yang mana ini menambahkan teori Steenbrink tentang empat faktor yang mendorong perubahan pendidikan Islam di Indonesia.

\section{Daftar Pustaka}

Azra, Azyumardi. 2012. Pendidikan Islam Tradisi Dan Modernisasi Di Tengah Tantangan Millenium III. Jakarta: Kencana.

Azra, Azyumardi. 2013. Edisi Perenial Jaringan Ulama Timur Tengah Dan Kepulauan Nusantara Abad XVII EE XVIII Akar Pembaharuan Islam Nusantara. Cet. ke-1. Jakarta: Kencana.

Azra, Azyumardi. 2015. "Islam Washatiyah Indonesia: Distingsi Dan Legacy Untuk Aktualisasi Islam Rahmatan Lil "Alamin Dalam Peradaban Global.” In Makalah Disampaikan Pada Diskusi Kompas-Panitia Muktamar Nahdhatul Ulama "Meneguhkan Islam Nusantara," Gedung Unit II Kompas, Palmerah Barat, Jakarta, 1-12. 
Azra, Azyumardi, and Dina Afriyanti. 2005. "Pesantren and Madrasa: Modernization Of Indonesian Muslim Society." In Paper Presented Workshop on Madrasa, Modernity and Islamic Education, Boston University, Cura, 1-4.

Bruinessen, Martin Van. 1995. Kitab Kuning Pesantren Dan Tarekat Tradisi-Tradisi Islam Di Indonesia. Bandung: Mizan.

Dhofier, Zamakhsyari. 2011. Tradisi Pesantren Studi Pandangan Hidup Kyai Dan Visinya Mengenai Masa Depan Indonesia. Cet. ke-8. Jakarta: LP3ES.

Duderija, Adis. 2010. "Constructing the Religious Self and the Other: Neo-Traditional Salafi Manhaj." Islam and Christian-Muslim Relations 21(1): 75-93.

Duderija. 2014. "Islamic Groups and Their World-Views and Identities : NeoTraditional Salafis and Progressive Muslims Author ( S ): Adis Duderija Published by : BRILL Stable URL : http://www.jstor.org/stable/27650599 . JSTOR Is a Not-for-Profit Service That Helps Scholar.” 21(4): 341-63.

Irham. 2015. "Pesantren dan Perkembangan Politik Pendidikan Agama Di Indonesia.” Ta’lim Jurnal Pendidikan Islam 13(1): 93-118.

Noorhaidi. 2005. "Laskar Jihad Islam, Militancy and The Quest for Identity in Post-New Order Indonesia." Ph.D. Dissertation. Utrecht university.

Olsson, Susanne. 2012. "Swedish Puritan Salafism: A Hijra Within." Comparative Islamic Studies 8(1-2): 71-92. http://www.equinoxpub.com/journals/index. php/CIS/article/viewArticle/20939 accessed 6/6/2015.

Siradj, Said Aqiel. 2007. "Islam Wasathan Sebagai Identitas Islam Indonesia." Tashwirul Afkar (22): 74-79.

Steenbrink, Karel A. 1994. Pesantren Madrasah Sekolah Pendidikan Islam Dalam Kurun Modern. cet. ke-2. Jakarta: LP3ES.

Wahid, Din. 2014a. "Book Review Kembalinya Konservatisme Islam Indonesia." Studia Islamika 21(2): 375-90.

Wahid. Din. 2014b. "Nurturing The Salafy Manhaj: A Study of Salafi Pesantrens In Contemporary." Utrecht University. 